\title{
Teachers' Experiences with Yoruba-English Bilinguals: Implications for Learning Yoruba and English in Public Primary School Classroom in Ekiti State, Nigeria
}

\author{
Oladunni O. Deji-Afuye and Felicia T. Obadare \\ Bamidele Olumilua University of Education, Science and Technology, Ikere-Ekiti, Nigeria
}

\begin{abstract}
This study investigated teachers' experiences with Yoruba-English bilinguals in public primary schools in Ekiti State. The sample used for this study consisted of one hundred (100) public primary schools teachers in the state. A simple selfdeveloped questionnaire was used to get information from the respondents regarding their experiences with their pupils concerning the pupils' communication behaviour and competence in Yoruba and English. The research hypothesis was tested at 0.05 level of significance during the study. The findings showed that the pupils found it relatively more comfortable to communicate in their mother tongue than in the English language; that the issue of general preference for the use of English in the Nigerian educational sector which had imposed communication in the language on the pupils and their teachers was a major factor constraining the use of mother tongue at the elementary schools; and that teachers had resorted to the use of code mixing/switching to ensure pupils' learning and understanding. These findings indicated that there were significant effects of English-Yoruba bilingualism on Yoruba and English learning among public primary school pupils in Ekiti State. This has negatively affected the learning of both languages by the pupils. Thus, the study recommended that the implementation of early Mother Tongue instruction should be made workable by ensuring adequate development of the mother tongue; teachers' competence in the mother tongue; availability of teaching materials to be used and proper monitoring of the school to follow the stipulations in the policy.
\end{abstract}

Key words: experiences, bilingual, mother tongue, teaching, learning, indigenous language.

\section{INTRODUCTION}

$\mathrm{E}$ ven though Nigeria has over four hundred indigenous languages as well as a number of non-indigenous ones, English has gained more prominence than any of the languages. One of the things indicating the aforementioned issue is the widespread of bilingualism among Nigerians. The multilingual nature of the country has created much room for English to be considered as a unifying language. The knowledge of English is a plus to any Nigerian child as it is the instrument with which we determine the quality and quantity of education possessed by the users (Deji-Afuye \& Obadare, 2019). This explains why both literate and nonliterate accord respect for whoever has good proficiency in English. This further explicates why the situation of the country is now evolving semi-exoglossic bilingualism whereby English and one indigenous language are learned mostly by the educated ones.

The present language learning environment in Nigeria has been created by the contact and conflict that exist between the English language and the indigenous languages whereby, according to Dada (2007), the indigenous languages are already conquered by the English language. Hence, most learners are now exposed to indigenous languages that have been influenced by English. Moreover, the dominance of English at the present has obviously reduced the use of the indigenous languages among Nigerians, especially children (Adegbite \& Babalola, 2008; Ajepe \& Ademowo, 2016). The fact remains that children are no longer encouraged to acquire their mother tongue as their first language. Instead, some are exposed to both the mother tongue and the second language at virtually the same time with more preference for English while some are not even given any opportunity to have a taste of their mother tongue at all.

From the foregoing, it is apparent that English has influenced many Nigerian indigenous languages in a number of ways. According to Akere (2004) not only has the English language provided some lexical items that have been loaned and assimilated into these indigenous languages, it has also influenced the linguistic habits of many Nigerian bilinguals in their mother tongue and the English language. Furthermore, in the words of Akere (2004: 276),

There are many literate Nigerians today who command native-speaker competence (spoken and written) in English language. But, although they can speak their mother tongue, they cannot produce any lengthy discourse in it; and, for many of them, it is just an impossible task for them to write an informal letter to their friends and close relations. Many of them cannot deliver a public address in their mother tongue.

Oluga and Babalola (2012) have noted that there are several implications for the decline in the use of the indigenous languages. One of these implications is a situation whereby learners are becoming semi-lingual or limited bilinguals 
(Dada, 2007). This refers to the situation whereby the individuals involved have limited proficiency in both languages, that is, the mother tongue and the second language.

\section{Language Learning Situation in Ekiti State}

Ekiti state (located in the South-Western region of Nigeria) is a bilingual speech community having Ekiti dialect (a Yoruba language variety) and English as the major languages. Looking at the language learning situation in the state, like in many other states in Nigeria, most educated elites have preference for English even at the expense of their native language/dialect (Deji-Afuye and Obadare, 2015). Such people perceive English to be the language of the elite and that of upward social mobility, thus prefering their children or wards to learn and speak English instead of learning the indigenous language. Adegoju (2002:129) notes:

It is a common knowledge that most (educated)
Yoruba parents force their children to adopt English
as the first language and the only language that
matters for international and academic purposes.
The indigenous language, if the child would learn at
all, would come very much later after the child must
have supposedly acquired enough English to sustain
his/her academic endeavours. The indigenous
language; Yoruba, then becomes an alien song to the
child.

Ayoola and Soneye (2015) observe that this trend of preference for English practically started from Lagos state (a major south-west Nigerian metropolis) where the use of mother tongues was almost a taboo in many homes and primary schools. This tendency has been extended to other Yoruba states like Ekiti. In many nursery and primary schools as well as the homes of many educated elites in Ekiti state, English has taken over. At present, this trend is being mimicked by the lower classes in the speech community. Adegbite (2010) observes that even less educated parents, who are often not proficient in speaking English, emulate this practice.

One of the adverse effects of the dominance of English over the indigenous languages is that most of the bilinguals can no longer express themselves in their mother tongue because of the struggle to learn/speak English and the mode of acquisition of the said English is far from being native-like. The mother tongue spoken is no longer 'pure'; code mixing and code switching are the order of the day. Hardly can one find an educated Yoruba bilingual who can speak Yoruba without code mixing with English (Owolola, 2018). This situation has been extended to children. The Yoruba language that children are acquiring now is a 'new' variety which is code mixed with English. The consequence of this is a situation whereby proficiency in both languages is not fully developed.

\section{Statement of the Problem}

From the studies of several language scholars in Nigeria, it has been observed that because of the many functions and impact of English worldwide, many Nigerians prefer learning English to learning any of the indigenous languages. Thus, most learners, especially children, are not adequately encouraged to learn their mother tongue and at the same time, the English they learn is hampered as a result of the effects of the non-native environment where it is being learned. In addition to that, the contact between English and the indigenous languages has brought about the interference of both languages on each other. This interference has caused a major setback among a number of young Yoruba-English bilinguals in the sense that they can no longer speak their mother tongue fluently neither are they proficient in the use of the English language. Adegbite (2009:91) mentions this problem thus, "Because many children are encouraged to learn English without giving due regard to their mother tongue, the children end up failing to achieve mastery of either language." Therefore, this study aims at exploring the experiences of teachers of English with the Yoruba-English limited bilinguals in order to bring to fore whether they are really making headway teaching the English language effectively.

\section{Research Questions}

1. What are the teachers' perceptions of pupils' communication behaviour and competence?

2. What are teachers' experiences with Yoruba-English bilingual pupils regarding pupils' communication behaviour and competence?

3. What are the effects of Yoruba-English bilingualism on the learning of Yoruba and English languages among primary school pupils in Ekiti State?

\section{Research Hypothesis}

1. There is no significant effect of English-Yoruba bilingualism on the learning of Yoruba and English languages among primary school pupils in Ekiti State.

\section{METHODOLOGY}

The research design used for this study was survey design of descriptive research. This type of design is considered to be suitable for this study because it allowed a wide coverage of the targeted population of the study. It enabled us to explore within a limited time teachers' experiences with the YorubaEnglish bilinguals and the extent of their achievement in teaching Yoruba and English languages in primary school. The population for the study included all teachers in public primary schools in Ikere Local Government Area of Ekiti State. As at the time of this study, there are 12 government owned primary schools in the study area, out of which, simple random sampling technique was used to select 10 schools and 10 teachers from each school making a total of 100 teachers as sample for the study. The instrument used for data collection was a self-designed questionnaire titled: Teachers' 
Experiences with Yoruba-English Bilinguals in Primary School Classroom (TEYEBPSC). The questionnaire has two sections, A and B. Section A of the TEYEBPSC comprises the subjects' biodata. Section B contains questions on teachers' perceptions and experiences with Yoruba-English Bilinguals. A four likert scale questionnaire items was provided to elicit responses from the participants. The scores obtained by each respondent were used to analyze the data.
Data analysis was conducted using descriptive and inferential statistics (chi-square $\left(\mathrm{X}^{2}\right)$ at 0.05 level of significance.

\section{DATA ANALYSIS AND FINDINGS}

Question 1: What are the teachers' perceptions of pupils' communication behaviour and competence?

Table 1: Teachers' perceptions of pupils' communication behaviour and competence

\begin{tabular}{|c|c|c|c|c|c|c|c|}
\hline $\mathrm{S} / \mathrm{N}$ & Items & SA & A & $\mathrm{D}$ & $\mathrm{SD}$ & Mean & Decision \\
\hline 1. & $\begin{array}{l}\text { Pupils find it difficult to understand some subjects without } \\
\text { the use of Yoruba. }\end{array}$ & $45(45 \%)$ & $50(50 \%)$ & $5(5 \%)$ & $0(0)$ & 3.40 & Agreed \\
\hline 2. & $\begin{array}{l}\text { It is necessary for teachers to use pupils' mother tongue for } \\
\text { effective communication to take place. }\end{array}$ & $50(50 \%)$ & $30(30 \%)$ & $15(15 \%)$ & $5(5 \%)$ & 3.85 & Agreed \\
\hline 3. & $\begin{array}{l}\text { Pupils express themselves better in their mother tongue } \\
\text { than in English. }\end{array}$ & $50(50 \%)$ & $45(45 \%)$ & $0(0)$ & $5(5 \%)$ & 3.40 & Agreed \\
\hline 4. & Pupils are addicted to the use of their mother tongue. & $45(45 \%)$ & $45(45 \%)$ & $10(10 \%)$ & $0(0)$ & 3.35 & Agreed \\
\hline 5. & Pupils are neither good in the use of English nor Yoruba. & $35(35 \%)$ & $25(25 \%)$ & $20(20 \%)$ & $20(20 \%)$ & 2.75 & Agreed \\
\hline 6. & $\begin{array}{l}\text { Pupils have a more positive attitude to the use of Yoruba } \\
\text { than English. }\end{array}$ & $40(40 \%)$ & $55(55 \%)$ & $0(0)$ & $5(5 \%)$ & 3.30 & Agreed \\
\hline 7. & $\begin{array}{l}\text { School rules do not permit frequent use of Yoruba in } \\
\text { teaching. }\end{array}$ & $45(45 \%)$ & $35(35 \%)$ & $0(0)$ & $15(15 \%)$ & 3.00 & Agreed \\
\hline 8. & $\begin{array}{l}\text { Preference for English language imposes communication } \\
\text { in English on pupils. }\end{array}$ & $40(40 \%)$ & $50(50 \%)$ & $0(0)$ & $10(10 \%)$ & 3.20 & Agreed \\
\hline 9. & $\begin{array}{l}\text { Teachers prefer communicating with their pupils in } \\
\text { Yoruba. }\end{array}$ & $20(20 \%)$ & $20(20 \%)$ & $20(20 \%)$ & $40(40 \%)$ & 2.20 & Disagreed \\
\hline 10. & $\begin{array}{l}\text { Pupils prefer communicating with their teachers in } \\
\text { English. }\end{array}$ & $20(20 \%)$ & $70(70 \%)$ & $0(0)$ & $10(10 \%)$ & 2.60 & Agreed \\
\hline 11. & Pupils prefer communicating with their peers in Yoruba. & $45(45 \%)$ & $40(40 \%)$ & $0(0)$ & $15(15 \%)$ & 3.15 & Agreed \\
\hline 12. & $\begin{array}{l}\text { Pupils usually code-mix Yoruba and English as they } \\
\text { communicate in Yoruba. }\end{array}$ & $25(25 \%)$ & $65(65 \%)$ & $0(0)$ & $10(10 \%)$ & 3.05 & Agreed \\
\hline 13. & Pupils are more proficient in English than Yoruba. & $30(30 \%)$ & $10(10 \%)$ & $25(25 \%)$ & $35(35 \%)$ & 2.35 & Disagreed \\
\hline & \multicolumn{5}{|c|}{ Grand Mean } & 3.05 & Agreed \\
\hline
\end{tabular}

Source: Field Work (2021)

Table 1 reveals teachers' perceptions of pupils' communication behaviour and competence. It was revealed that the majority of the respondents agreed to the statements in items $1-8$ as well as items $10-12$ because their mean values were greater than 2.50. This implies that pupils find it difficult to understand some subjects without the use of Yoruba (3.40); it is necessary for teachers to use pupils' mother tongue for effective communication to take place (3.85); pupils express themselves better in their mother tongue than in English (3.40); pupils are addicted to the use of their mother tongue (3.35); pupils are neither good in the use of English nor Yoruba (2.75); pupils have more positive attitude to the use of Yoruba than English (3.30); school rules do not permit frequent use of Yoruba in teaching (3.00); preference for English imposes communication in English on pupils (3.20); pupils prefer communicating with their teachers in English (2.60); pupils prefer communicating with their peers in Yoruba (3.15) and pupils usually code-mix Yoruba and English as they communicate in Yoruba (3.05). The statements in item 9 and 13 were disagreed by the respondents as the mean values were less than 2.50. This implies that teachers did not prefer communicating with their pupils in Yoruba and pupils were more proficient in Yoruba than English. The grand mean (3.05) in the table was greater than 2.50 which implies that teachers believed that pupils speak more of mother tongue in the school and try to code-mix Yoruba and English as they communicate in Yoruba.

Question 2: What are teachers' experiences with YorubaEnglish bilingual pupils regarding pupils' communication behaviour and competence?

Table 2: Teachers' Experiences with Yoruba-English Bilingual Pupils regarding Pupils' Communication Behaviour and Competence?

\begin{tabular}{|c|c|c|c|c|c|c|}
\hline Code & Variables & $\begin{array}{c}\text { Very } \\
\text { good } \\
-4\end{array}$ & $\begin{array}{c}\text { Good } \\
-3\end{array}$ & $\begin{array}{c}\text { Average } \\
-2\end{array}$ & $\begin{array}{c}\text { Poor } \\
-1\end{array}$ & Score \\
\hline \multirow{4}{*}{$\begin{array}{l}\text { Pupils' } \\
\text { oral } \\
\text { and } \\
\text { written } \\
\text { English }\end{array}$} & Fluency & & & $\mathrm{X}$ & & 2 \\
\hline & $\begin{array}{c}\text { Grammatical } \\
\text { accuracy }\end{array}$ & & & & $\mathrm{X}$ & 1 \\
\hline & Vocabulary & & & $X$ & & 2 \\
\hline & Pronunciation & & & $\mathrm{X}$ & & 2 \\
\hline & \multicolumn{5}{|c|}{ Total } & 7 \\
\hline
\end{tabular}




\begin{tabular}{|c|c|c|c|c|c|c|}
\hline \multirow{2}{*}{$\begin{array}{c}\text { Pupils' } \\
\text { oral } \\
\text { and } \\
\text { written } \\
\text { Yoruba }\end{array}$} & $\begin{array}{c}\text { Gluency } \\
\text { Grammatical } \\
\text { accuracy }\end{array}$ & & $\mathrm{X}$ & & & 3 \\
\hline & Vocabulary & & & $\mathrm{X}$ & & 2 \\
\hline & Pronunciation & & $\mathrm{X}$ & & & 3 \\
\hline & \multicolumn{3}{|c|}{ Total } & 11 \\
\hline
\end{tabular}

Source: Field Work (2021)

Table 2 shows teachers' understanding regarding pupils' oral and written proficiencies in English and Yoruba languages. The coding marks in table two revealed that pupils are average in their fluency, vocabulary and pronunciation in English language but poor in English grammatical accuracy. However, the pupils were found to be good in their fluency, grammatical accuracy, and pronunciation in Yoruba language and average in Yoruba vocabulary. This shows that the pupils were more competent in Yoruba language than English language. Nevertheless, the pupils were yet to acquire adequate vocabulary in both languages.

Table 3: Teachers' Experiences comparing the use of English and Yoruba among the Pupils

\begin{tabular}{|c|c|c|c|c|c|c|}
\hline Code & Variable & $\begin{array}{c}\text { Very } \\
\text { High }\end{array}$ & High & Low & $\begin{array}{c}\text { Very } \\
\text { low }\end{array}$ & Mean \\
\hline $\begin{array}{c}\text { English } \\
\text { and } \\
\text { Yoruba }\end{array}$ & $\begin{array}{c}\text { Code Mixing } \\
\text { (English and } \\
\text { Yoruba) }\end{array}$ & $\mathrm{X}$ & & & & \multirow{2}{*}{4.00} \\
\hline \multirow{2}{*}{ English } & $\begin{array}{c}\text { Pronunciation } \\
\text { Problems }\end{array}$ & & $\mathrm{X}$ & & & \\
\cline { 2 - 6 } & Direct translation & & & & $\mathrm{X}$ & \\
\hline
\end{tabular}

\begin{tabular}{|c|c|c|c|c|}
\hline & $\begin{array}{c}\text { from English to } \\
\text { Yoruba }\end{array}$ & & & \multirow[t]{3}{*}{2.50} \\
\hline & Vocabulary Errors & $\mathrm{X}$ & & \\
\hline & Grammatical Errors & $\mathrm{X}$ & & \\
\hline \multirow{4}{*}{ Yoruba } & $\begin{array}{c}\text { Pronunciation } \\
\text { Problem }\end{array}$ & & $X$ & \multirow{4}{*}{2,25} \\
\hline & $\begin{array}{l}\text { Direct translation } \\
\text { from Yoruba to } \\
\text { English }\end{array}$ & $\mathrm{X}$ & & \\
\hline & Vocabulary Errors & & $\mathrm{X}$ & \\
\hline & Grammatical Errors & & $\mathrm{X}$ & \\
\hline
\end{tabular}

Source: Field work, 2021

Table 3 summarises the experiences of teachers comparing the use of English and Yoruba among the pupils. The table reveals that the rate at which pupils code-mixed Yoruba and English while speaking Yoruba was very high (4.00). On one hand, in the use of English by the pupils, pronunciation problems, vocabulary and grammatical errors were high while direct translation from English to Yoruba was very low (2.50). On the other hand, pronunciation problems, vocabulary errors and grammatical errors were low in the pupils' use of Yoruba with high direct translation from Yoruba to English (2.25).

Question 3: What are the effects of English-Yoruba bilingualism on the learning of Yoruba and English languages among primary school pupils in Ekiti State?

Table 4: Effects of English-Yoruba Bilingualism on the learning of Yoruba and English Languages among Primary School Pupils in Ekiti State

\begin{tabular}{|c|c|c|c|c|c|c|c|}
\hline S/N & Items & SA & A & D & SD & Mean & Decision \\
\hline 1. & $\begin{array}{c}\text { The shift from mother tongue to English has negatively } \\
\text { affected the mastery of Yoruba among the pupils. }\end{array}$ & $30(30 \%)$ & $40(40 \%)$ & $10(10 \%)$ & $20(20 \%)$ & 2.80 & Agreed \\
\hline 2 & $\begin{array}{c}\text { The shift from mother tongue to English has positively } \\
\text { affected the mastery of English among the pupils. }\end{array}$ & $10(10 \%)$ & $10(10 \%)$ & $30(30 \%)$ & 45 & 1.75 & Disagreed \\
\hline 3. & $\begin{array}{c}\text { The percentage of pupils who speak English at home is } \\
\text { less than those who speak Yoruba. }\end{array}$ & $25(25 \%)$ & $45(45 \%)$ & $10(10 \%)$ & $20(20 \%)$ & 2.75 & Agreed \\
\hline 4. & $\begin{array}{c}\text { Pupils usually perform better in Yoruba as a subject than } \\
\text { English as a subject. }\end{array}$ & $40(40 \%)$ & $5(5 \%)$ & $30(30 \%)$ & $25(25 \%)$ & 2.60 & Agreed \\
\hline 5. & $\begin{array}{c}\text { Pupils are more exposed to Yoruba than English both at } \\
\text { home and school. }\end{array}$ & $25(25 \%)$ & $45(45 \%)$ & $10(10 \%)$ & $20(20 \%)$ & 2.75 & Agreed \\
\hline 6. & Pupils' attitude towards native culture is negative. & $5(5 \%)$ & $30(30 \%)$ & $30(30 \%)$ & $35(35 \% 0$ & 2.05 & Disagreed \\
\hline 7 & Pupils' attitude towards target culture is negative. & $15(15 \%)$ & $55(55 \%)$ & $15(15 \%)$ & $15(15 \%)$ & 2.70 & Agreed \\
\hline & \multicolumn{2}{|c|}{ Grand Mean } & & 2.50 & \\
\hline
\end{tabular}

Source: Field Work, (2021)

The analysis in Table 4 reveals the effects of English-Yoruba bilingualism on the learning of Yoruba and English languages among primary school pupils in Ekiti State. It was revealed that majority of the respondents agreed with the statements in items $1,3,4,5$ and 7 indicating that the shift from mother tongue to English has negatively affected the mastery of Yoruba among the pupils (2.80), the percentage of pupils who speak English at home is less than those who speak Yoruba (2.75), pupils usually perform better in Yoruba as a subject than English as a subject (2.60), pupils are more exposed to
Yoruba than English both at home and school (2.75) and pupils' attitude towards target culture is negative (2.70) while they disagreed with items 2 and 6 indicating that the shift from mother tongue to English has not positively affected the mastery of English among the pupils (1.75) and pupils' attitude towards native culture is not negative (2.05). The grand mean value in the table indicated that there are negative implications of English-Yoruba bilingualism on English language learning among primary school pupils in Ekiti State. 


\section{Test of Hypothesis}

$H_{01}$ : There is no significant effect of English-Yoruba bilingualism on English language learning among primary school pupils in Ekiti.

Table 5: Analysis of Variance (ANOVA) for effects of English-Yoruba Bilingualism on the Learning of Yoruba and English Languages among Primary School Pupils in Ekiti State

\begin{tabular}{|c|c|c|c|c|c|c|}
\hline & $\begin{array}{c}\text { Sum of } \\
\text { Squares }\end{array}$ & Df & $\begin{array}{c}\text { Mean } \\
\text { Square }\end{array}$ & F-Cal & F-Tab & Sig. \\
\hline $\begin{array}{c}\text { Between } \\
\text { Groups }\end{array}$ & 43.008 & 1 & 43.008 & 310.268 & 4.860 & .000 \\
\hline $\begin{array}{c}\text { Within } \\
\text { Groups }\end{array}$ & 55.169 & 98 & .139 & & & \\
\hline Total & 98.178 & 99 & & & & \\
\hline
\end{tabular}

$\mathrm{P}<0.05$ (Significant)

The result presented in Table 5 revealed that F-Cal (310.268), $\mathrm{df}=(1,98), \mathrm{P}<0.05$ at 0.05 level of significance was significant. This led to the rejection of the hypothesis. Hence, there are significant effects of English-Yoruba bilingualism on Yoruba and English learning among primary school pupils in Ekiti State.

\section{DISCUSSION}

The findings of this study from Table 1 show that pupils find it difficult to understand some school subjects without the use of their mother tongue. It is, therefore, necessary for teachers to teach pupils in their mother tongue for effective communication to take place. This corroborates the arguments of a number of scholars among whom are Abidogun \& Adebule (2013), Awopetu (2016); Akintoye (2017) and Akintunde \& Akuta (2021) who argued that pupils learn better when they are taught in their mother tongue. It was also revealed that pupils express themselves better in Yoruba than English; have a more positive attitude to Yoruba than English and prefer to communicate with their peers in Yoruba than in English as they are more proficient in Yoruba than English. The reason can be traced to the fact that Yoruba is the language which the pupils acquired naturally and in which they have more intuitive knowledge (Abidogun \& Adebule, 2013). Hence, regardless of the imposed restriction on the use of English in the classroom, whenever the teacher is not around, the pupils revert or switch to Yoruba (the indigenous language). This shows that the pupils find it relatively more comfortable to communicate in their mother tongue than in the English language (Dada, 2007).

Even though it has been proven that pupils learn better when they are taught in their mother tongue and that according to the findings of this study, pupils are more comfortable using their mother tongue than the English language, the school rules do not permit frequent use of Yoruba in the primary schools used for this study. Whereas the National Policy on Education (NPE) specifies the use of the child's mother tongue as a medium of instruction for the first three years of basic education (Akintunde \& Akuta, 2021). There is the need to also note that there has been weak implementation of this early Mother Tongue instruction which should have been the best medium of instruction in elementary education. This is due several factors such as limitation in the teachers' competence in the mother tongue; non-availability of teaching materials to be used and inadequate development of the mother tongue. Many of the teachers therefore, resort to the use of code-switching between English and Yoruba in order to stand in the 'balance' (Akintoye, 2017). The issue of general preference for English which has imposed its use on the pupils and their teachers is one of the factors constraining the use of mother tongue at the elementary schools as it has been stated in National Policy on Education in Nigeria.

Tables 2 and 3 reveal teachers' experiences regarding pupils' communication behaviour and competence as well as the effect of the interference that exist between English and Yoruba on the pupils' language learning. The findings in Table 2 show that the pupils were more competent in Yoruba language than English language. Nevertheless, the pupils were yet to acquire adequate vocabulary in both languages. This indicates why they are deficient in both languages. As noted by Adegbite (2009) and Owolabi (2014), the inevitable interference in both languages under study and the frequent exposure to one of them, that is, the mother tongue has made effective acquisition of the two languages difficult to the extent that the pupils are not reasonably proficient in either.

The findings as revealed in table 3 indicate that the rate at which pupils code-mixed Yoruba and English while speaking Yoruba is very high. On one hand, it was also revealed that in the use of English by the pupils, pronunciation problems, vocabulary and grammatical errors were high while direct translation from English to Yoruba was very low. On the other hand, pronunciation problems, vocabulary errors and grammatical errors were low in the pupils' use of Yoruba. There was a high direct translation from Yoruba to English. The reasons behind this scenario have also been explained by Owolola (2018) who identified a number of the effects of the interference in the contact between the two languages. When languages come in contact, it is not without some inevitable consequences, which may be auspicious to one and adverse to the other.

The findings of this study also state that there are significant effects of English-Yoruba bilingualism on Yoruba and English language learning among public primary school pupils in Ekiti State. According to the teachers who responded to the researcher's interrogations, it has come to a situation whereby teachers would have to translate certain lexical items in Yoruba to English or English to Yoruba before the pupils could understand them. Many of the teachers have, therefore, resorted to the use of code mixing and code switching in order to ensure the pupils understand what they are being taught. As noted by Dada (2007), the linguistic interference or language transfer that exists between both languages is a main impediment to the learning of the languages. 


\section{CONCLUSION}

The experiences of teachers in the context of this study reveal the negative effects of the interference between English and Yoruba on the learning of both languages by the pupils they teach. The language of the environment in which a child develops determines what language the child picks up. The environment of the pupils has been dominated with preference for English. Nevertheless, Yoruba is still predominantly spoken in the homes of most of the pupils involved in this study, because their parents are semi-literates and illiterates who also have preference for English. Owolabi (2014) notes that even though the majority of such children are exposed to English in a way, they are not that proficient in it; neither are they proficient in their mother tongue. The fact remains that the shift from mother tongue to English has negatively affected the mastery of both the mother tongue and the English language. From the findings of this study there is the indication that the pupils concerned are more of subtractive bilinguals than any other type. This has been a major challenge to the teachers in our public primary schools. It is therefore recommended that:

1. Parents should be made to understand that the schooling system and the communities are supposed to be extensions of each other such that there would be an unbroken transition from home/community to school in regard to language use.

2. Teachers should be conversant with the effects of language contact on the individual learners and as such plan, prepare and ensure that learners are actually learning.

3. Government should make the implementation of National Policy on Education (NPE), (that is early Mother Tongue instruction) workable by ensuring adequate development of the mother tongue; teachers' competence in the mother tongue; availability of teaching materials to be used, and proper monitoring of the school to follow the stipulations in the policy.

\section{REFERENCES}

[1] Abidogun, B. G. \& Adebule, O. I. (2013). Contributions of Mother Tongue Education in early childhood Education, $1^{\text {st }}$ Annual International Interdisciplinary conference, Portugal Proceedings, pp 267-272 URL: http://eujournal.org/files/journal/1/articles/1337/public/1337-43401-PB.pdf
[2] Adegbite, A. B. (2010). English Language usage: uses and misuse(s) in a non-host Second Language Context Nigeria, Inaugural Lecture Series 231, OAU, Ile Ife.

[3] Adegbite, W. (2009). The Psycholinguistics of English Language in Nigeria. Ibadan: Kraft Books.

[4] Adegbite, W. \& Babalola, E. T. (2008). Sociological Dimensions of Bilingual Communication in Yoruba and English in a Cosmopolitan City: A Case Study of Ibadan land. Glossa: An Ambilingual Multidisciplinary Journal. (ISSN 1931-7778), Puerto Rico. http://bibliotecavirtualut.suagm.edu/glossa2/index.html

[5] Adegoju, A. (2002).Towards Re-focusing Indigenous Languages for Sanctity: The Yoruba Example. AAU: African Studies Review. 1 (1):129-139.

[6] Ajepe, I. \& Ademowo, A. J. (2016). English Language Dominance and the Fate of Indigenous Languages in Nigeria. International Journal of History and Cultural studies. 2(4):10-17.

[7] Akere, F. (2004). Nigerian English in Sociolinguistic Perspectives: Users and Emerging Varieties. In Dadzie, A. B. K. and Awonusi Segun (Eds.). Nigerian English: influences and Characteristics. Lagos: Concept Publications.

[8] Akintoye, J. (2017). A Survey of Teachers' Experience in Implementing Yoruba Medium of Instruction in the lower Primary Schools in Ikire, Nigeria. National Research University Higher School of Economics Journal of Language and Education. 3(4):615.

[9] Akintunde, A. F. \& Akuta, F. O. (2021). The significance of Mother Tongue in Early Chidhood Education. Sapientia Foundation Journal of Education, Science and Gender Studies. (3)1:21-29.

[10] Awopetu, A. V. (2016). Impact of Mother Tongue on Children's Learning Abilities in Early Childhood Classroom. Procedia Social and Behavioral Sciences. 233:58-63.

[11] Ayoola, K. A. \& Soneye, T. O. (2017). Mother Tongue Eclipsing in the Linguistic Repertoire of Yoruba/English Bilingual Children in Nigeria. Legon Journal of the Humanities. 27(1):95-118.

[12] Dada, S. A. (2007). Language Contact and Language Conflict: The Case of Yoruba-English Bilinguals. Kansas Working Papers in Linguistics. 29:85-113.

[13] Deji-Afuye, O. O. \& Obadare F.T. (2019) Teaching English for communication: Pedagogy and Performance in Selected Secondary Schools in Ado Ekiti, Nigeria. International Journal of Academic Research in Education and Review (IJARER). 7(2):2127.

[14] Obadare F.T. \& Deji-Afuye, O. O (2015) Parental Attitude to the Use of English of the Girl-Child:A Panacea for Crime against Women in Ikere-Ekiti, Nigeria. International Journal of Innovative Education Research (IJIER). 3(4):8-14.

[15] Oluga, S. O. \& Babalola, H. A. L. (2012). Official use of English and the Resultant Marginalisation of Indigenous Languages: The Cases of the three major Nigerian Languages. European Journal of Social Sciences. 32(4):619-631.

[16] Owolabi, D. (2014). Language Pattern of Yoruba-English Teenage School-going Bilinguals in Southwest Nigeria: Impact on the English language and suggestions for Language Planning. Journal of Advances in Linguistics. 1(1):24-34.

[17] Owolola, O. (2018). A Sociolinguistic Study of the Effects of Yoruba-English Code-Mixing on the Yoruba language. Jurnal Arbitrer. 5(1):23-30. 